\title{
Astyanax elachylepis, a new characid fish from the rio Tocantins drainage, Brazil (Teleostei: Characidae)
}

\author{
Vinicius A. Bertaco* and Paulo H. F. Lucinda**
}

A new characid species, Astyanax elachylepis, is described from the rio Tocantins drainage. The new species is distinguished from its congeners by possessing 48-53 perforated scales along the lateral line, a large caudal-peduncle spot, the presence of bony hooks on dorsal, anal, pelvic, and pectoral fins of males, one or two vertically-elongated humeral spots, one maxillary tooth, and 22-27 branched anal-fin rays.

Uma nova espécie de caracídeo, Astyanax elachylepis, é descrita da drenagem do rio Tocantins. A nova espécie distingue-se de suas congêneres pela presença de 48-53 escamas perfuradas na linha lateral, uma grande mancha sobre o pedúnculo caudal, uma ou duas manchas umerais verticalmente alongadas, um dente no maxilar e 22-27 raios ramificados na nadadeira anal.

Key words: Neotropical, Characiformes, Astyanax microlepis, taxonomy.

\section{Introduction}

The genus Astyanax Baird \& Girard, 1854 is a speciose characid genus, including at least 86 valid species distributed from southern United States to central Argentina (Lima et al., 2003). Astyanax was first revised by Eigenmann (1921, 1927), whose accounts still constitute the sole all-inclusive review of the genus. Most subsequent papers either involve the description of new species or are taxonomic reviews of species occurring in restricted geographic areas of South and Central America. The systematics of the genus is further complicated by the lack of evidence corroborating its monophyly (Weitzman \& Malabarba, 1998).

The examination of Astyanax samples housed at the MCP and UNT collections allowed the discovery of an undescribed species of the genus from the rio Tocantins drainage. This paper intends to formally describe this new species.

\section{Methods and materials}

Counts and measurements followed Fink \& Weitzman (1974), with the exception of the number of scale rows below lateral line, which were counted from the scale row ventral to lateral line to the scale row nearest the first pelvic-fin ray. Vertebral counts, supraneurals, gill-rakers of the first arch, and procurrent caudal-fin-ray counts were taken from two cleared and stained (c\&s) paratypes were prepared according to Taylor \& Van Dyke (1985). Teeth counts were taken in all type specimens. Vertebral counts include the four vertebra of the Weberian apparatus and the terminal centrum, counted as one vertebra. Lower and upper jaws of one c\&s paratype prepared for SEM (scanning electronic microscopy).

Measurements were taken point to point with an electronic caliper on the left side of specimens whenever possible. All measurements other than standard length (SL) are expressed as a percents of SL except subunits of the head, which are expressed as a percents of head length (HL). Others abbreviations in the text: NEAMB-UFT - Núcleo de Estudos Ambientais, Universidade Federal do Tocantins.

Specimens examined belong to Academy of Natural Sciences of Philadelphia (ANSP), California Academy of Sciences, San Francisco (CAS), Museu de Ciências e Tecnologia, Pontifícia Universidade Católica do Rio Grande do Sul, Porto Alegre (MCP), Museum Comparative Zoology, Harvad (MCZ), Museo de Historia Natural de la Universidad del Cauca, Popayán (MHNUC), Museu de Zoologia da Universidade de São Paulo (MZUSP), Naturhistorisches Museum, Vienna (NMW), Swedish Museum of Natural History, Stockholm (NRM), Laboratório de Ictiologia Sistemática, Universidade Federal do Tocantins, Porto Nacional (UNT), and National

\footnotetext{
*Laboratório de Ictiologia, Museu de Ciências e Tecnologia, Pontifícia Universidade Católica do Rio Grande do Sul, Av. Ipiranga 6681, Caixa Postal 1429, 90619-900 Porto Alegre, RS, Brazil. e-mail: ubertaco@pucrs.br

**Laboratório de Ictiologia Sistemática, Universidade Federal do Tocantins, Campus de Porto Nacional, R. 3, Quadra $17 \mathrm{~s} / \mathrm{n}$ - Jardim dos Ipês, Caixa Postal 136, 77500-000 Porto Nacional, TO, Brazil. e-mail: lucinda@uft.edu.br
} 
Museum of Natural History, Smithsonian Institution, Washington D.C. (USNM).

\section{Astyanax elachylepis, new species Figs. 1-3}

Holotype. MCP 37568 (91.7 mm SL, male), ribeirão Arara about $500 \mathrm{~m}$ of the mouth of rio Maranhão at Rosariana, Niquelândia, Goiás, Brazil, approx. 1402'S 48²6’W, 14 Jul 1992, R. E. Reis, E. H. Pereira, J. P. da Silva \& L. A. Porto.

Paratypes. Brazil, Goiás: rio Tocantins drainage: MCP 15862 (2, 72.0-105.6 mm SL), ribeirão da Lage on road to fazenda Aranha (Codemin), Niquelândia, approx. 14²25'S 4845'W, 17 Jul 1992, same collectors of the holotype. MCP 15922 (1,91.1 mm SL), rio do Peixe, tributary of rio Bagagem, between Niquelândia and Colinas, Niquelândia, approx. 14²7'S 48 14 'W, 16 Jul 1992, same collectors of the holotype. MCP 16054 (15, 2 c\&s, 44.3-82.1 mm SL), collected with the holotype. UNT 740 (1, $74.9 \mathrm{~mm} \mathrm{SL})$, rio Maranhão, Niquelândia, approx. 14²0'23"S 4854'37"W, 13 Aug 1997, D. F. Moraes. MZUSP 40533 (112, 65.8-127.4 mm SL), ribeirão Macambira, next the bridge on road GO 112, Iaciara, approx.

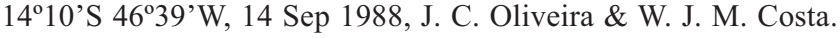
Pará: MZUSP 30258 (17, 94.6-117.5 mm SL), rio Itacaiunas, about $10 \mathrm{~km}$ E of N-4, Serra dos Carajás at Igarapé, approx. 0552'S $50^{\circ} 32^{\prime} \mathrm{W}, 13$ Oct 1983, M. Goulding. MZUSP 58093 (16, 93.0$138.3 \mathrm{~mm} \mathrm{SL}$ ), rio Itacaiunas, Caldeirão, Igarapé do Pojuca, approx. $05^{\circ} 52^{\prime}$ 'S 50³2'W, 15 Oct 1983, M. Goulding. Tocantins: UNT 1891 (10, 47.9-84.0 mm SL), rio das Pedras, São Salvador, approx. $12^{\circ} 39^{\prime} \mathrm{S}$ 48 $18^{\prime} \mathrm{W}, 5$ Aug 2004, NEAMB-UFT. UNT 2033 (36, 13.5-20.4 $\mathrm{mm}$ SL), lagoa da Ponte, near the bridge of the rio Tocantins, Porto Nacional, $10^{\circ} 52^{\prime}$ S $48^{\circ} 25^{\prime} \mathrm{W}, 11$ Nov 1995, NEAMB-UFT. UNT 2036 (1, $56.4 \mathrm{~mm} \mathrm{SL}$ ), córrego Sussuarana, Brejinho de Nazaré, approx. $11^{\circ} 01^{\prime}$ 'S 48 34'W, 15 Feb 2002, NEAMB-UFT. UNT 2037 (3, 78.8-96.5 mm SL), rio Paranã, fazenda Traçadal, Paranã, approx. $12^{\circ} 30^{\prime}$ 'S $48^{\circ} 12^{\prime} \mathrm{W}, 17$ Nov 1998, NEAMB-UFT. UNT 2157 (1, $98.6 \mathrm{~mm}$ SL), córrego Albano, near the mouth of rio Paranã, Paranã, approx. 12³4'S 4806'W, 9 Dec 1998, NEAMB-UFT. UNT 2158 (2, 94.1-114.1 mm SL), córrego Cipó, Paranã, approx. 12²9'S 48¹3'W, 26 Jan 1999, NEAMB-UFT.

Additional material (non types). Brazil, Goiás: UNT 739 (1, $91.4 \mathrm{~mm} \mathrm{SL}$ ), rio das Almas, approx. $14^{\circ} 37^{\prime} \mathrm{S} 49^{\circ} 03^{\prime} \mathrm{W}, 11$ Oct 1995. MZUSP 26519 (1, $103.5 \mathrm{~mm} \mathrm{SL})$, rio Resende, tributary of rio Vermelho, about $10 \mathrm{~km}$ of Buenolândia, approx. $15^{\circ} 49^{\prime} \mathrm{S} 50^{\circ} 19^{\prime} \mathrm{W}$, 7-13 Dec 1981. MZUSP 58622 (4, 100.8-117.5 mm SL), rio Angélica/ Bezerra, Parque Estadual de Terra Ronca, São Domingos, approx.

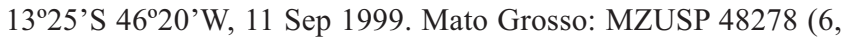
73.8-109.8 mm SL), córrego Fundo, tributary of left margin of rio Garças, rio Araguaia drainage, Barra do Garças, approx. $15^{\circ} 53^{\prime} \mathrm{S}$ 5247’W, 15 Nov 1993. Pará: MZUSP 58219 (1, 143.8 mm SL), igarapé Salobo, tributary of rio Itacaiunas, Parauapebas, $05^{\circ} 46^{\prime} 50^{\prime \prime} \mathrm{S}$ 50³2'48"W, Nov 1997. Tocantins: MZUSP 84116 (1, $64.5 \mathrm{~mm}$ SL), rio Palma, Conceição do Tocantins, approx. $12^{\circ} 22^{\prime} \mathrm{S} 47^{\circ} 03^{\prime} \mathrm{W}$, 1 Aug 2002. UNT 445 (1, $106.8 \mathrm{~mm} \mathrm{SL})$, rio Palmeiras drainage, tributary of the rio Palmas, rio Paranã drainage, approx. $12^{\circ} 10^{\prime} \mathrm{S}$ 46ํำ'W, 28 Oct 2002. UNT 1761 (1, $67.1 \mathrm{~mm} \mathrm{SL})$, córrego Albano, near the mouth of rio Paranã, Paranã, approx. $12^{\circ} 34^{\prime} \mathrm{S} 48^{\circ} 06^{\prime} \mathrm{W}, 4$ Aug 2004, NEAMB-UFT. UNT 1804 (1, $59.5 \mathrm{~mm}$ SL), rio das Lages, Paranã, approx. $12^{\circ} 35^{\prime}$ S 48 $02^{\circ}$ 'W, 3 Aug 2004, NEAMBUFT. UNT 1869 (1, 81.7 mm SL), córrego Calango, São Salvador, approx. 1244'S 4820'W, 4 Aug 2004, NEAMB-UFT. UNT 2153
(1, $91.1 \mathrm{~mm} \mathrm{SL})$; UNT 2159 (1, $102.7 \mathrm{~mm} \mathrm{SL),} \mathrm{sítio} \mathrm{Estrela,}$

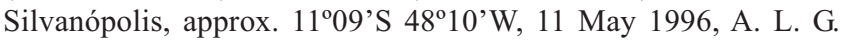
Borges. UNT 2154 (1, 62.4 mm SL), córrego Taboca, Paranã, approx. $12^{\circ} 29^{\prime}$ S 48 13 'W, 7 Aug 2000, NEAMB-UFT. UNT 2155 (1, 97.7 mm SL), rio Maranhão, fazenda Traçadal, Paranã, approx. 12²9'S $48^{\circ} 13^{\prime} \mathrm{W}, 2$ Mar 2000, NEAMB-UFT.

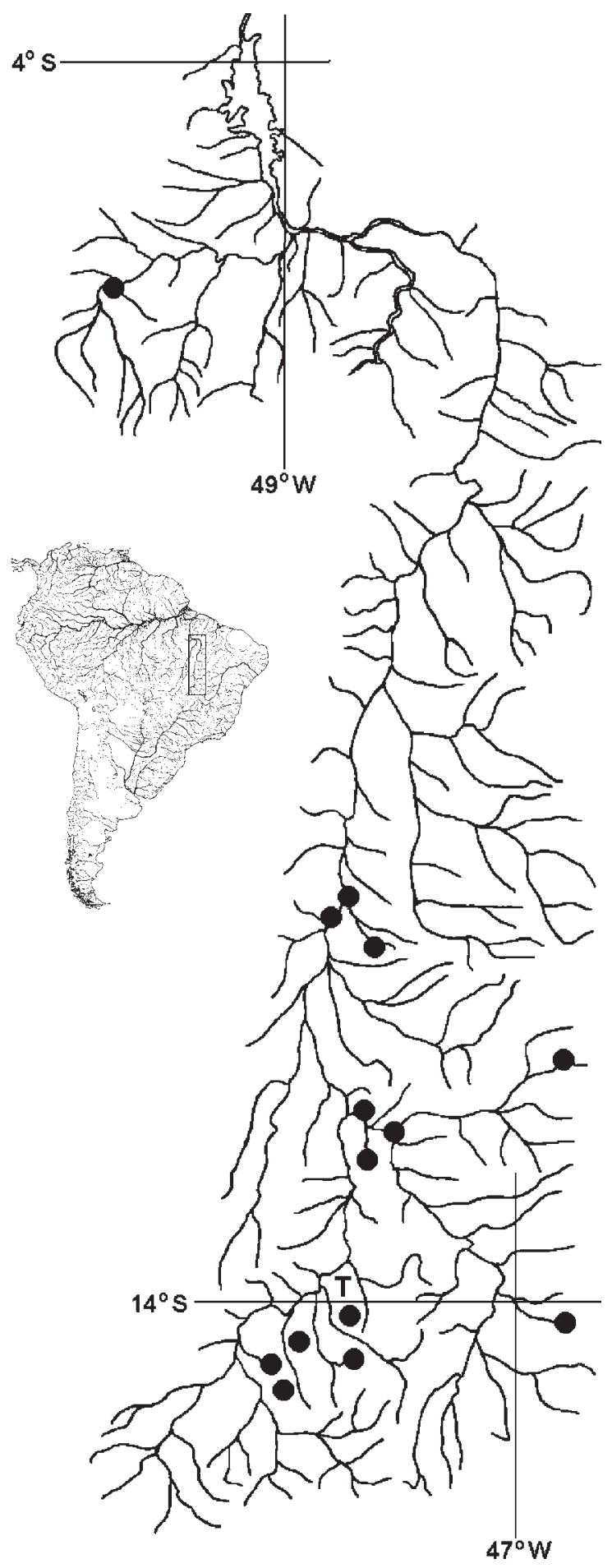

Fig. 1. Rio Tocantins drainage showing the collection localities of Astyanax elachylepis. Some symbols represent more than one lot or locality. $\mathrm{T}=$ type locality. 


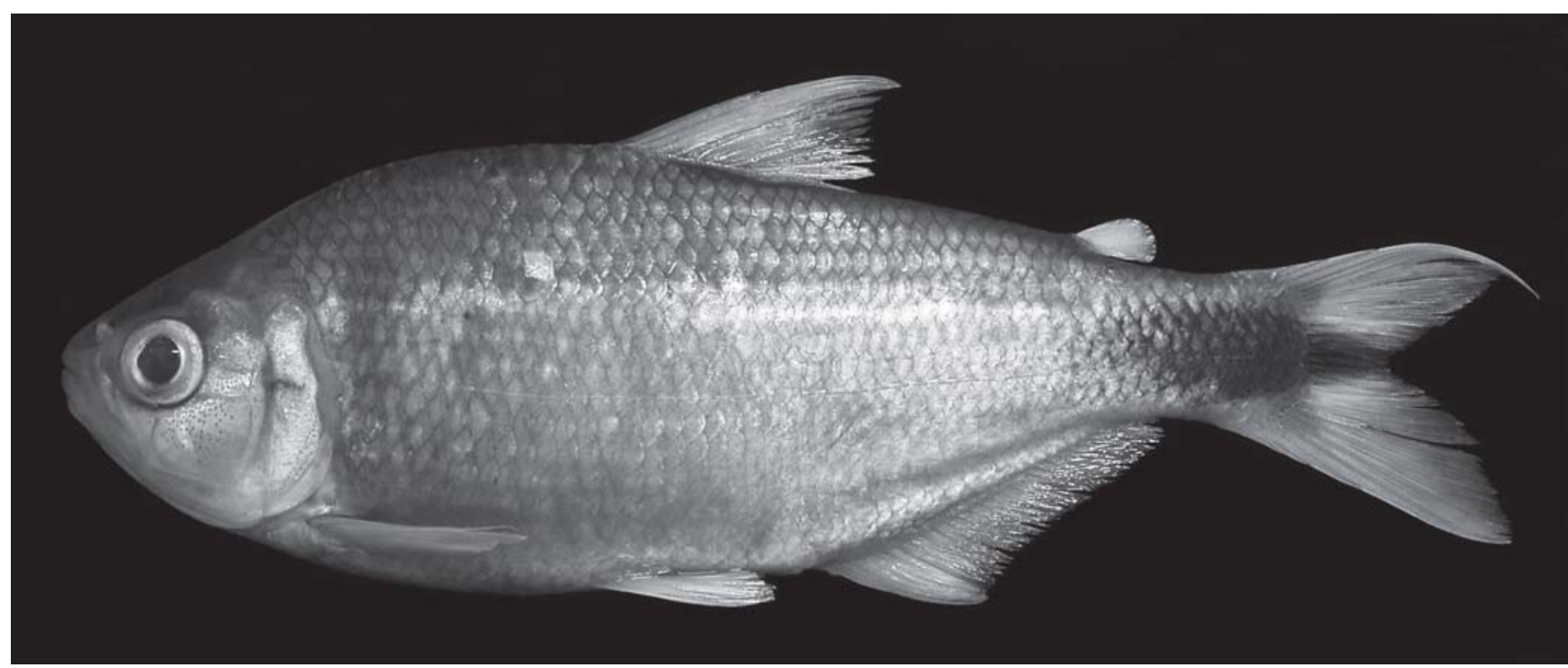

Fig. 2. Astyanax elachylepis, MCP 37568, holotype, male, $91.7 \mathrm{~mm}$ SL; ribeirão Arara about $500 \mathrm{~m}$ of the mouth of rio Maranhão at Rosariana, Niquelândia, Goiás, Brazil.

Diagnosis. Astyanax elachylepis is distinguished from its congeners, except $A$. anterior Eigenmann, 1908, A. bourgeti Eigenmann, 1908, A. erythropterus (Holmberg, 1891), A.festae (Boulenger, 1898), A. integer Myers, 1930, A. microlepis Eigenmann, 1913, A pellegrini Eigenmann, 1907, and $A$. symmetricus Eigenmann, 1908, by the higher number of lateral-line scales (48-53 vs 30-45, respectively). Astyanax elachylepis differs from the species listed above, except $A$. microlepis and $A$. anterior by a lower number of anal-fin rays (ii-iv, 22-27 vs 28-45). Astyanax elachylepis differs from $A$. microlepis by the number of branched anal-fin rays (22-27 vs 19-22), and by the presence of a large black caudal peduncle spot ( $v s$ absence of the caudal peduncle spot, or when present, smaller and approximately lozenge-shaped). Astyanax elachylepis differs from $A$. anterior by the presence of one or two vertically-elongated humeral spots ( $v s$ one ovate or horizontally elongated humeral spot). Furthermore, $A$. elachylepis differs from Astyanax species with high lateral line counts (the eight aforementioned species) by the presence of small bony hooks in dorsal-, anal-, pelvic-, and pectoral- fin rays of males $v s$ absence of bony hooks in dorsal- and pectoral- fin rays.

Description. Morphometric data summarized in Table 1. Body compressed and elongate; greatest body depth usually anterior to dorsal-fin origin. Dorsal head profile straight or slightly concave. Profile convex from supraocciptal tip to base of last dorsal-fin ray, and straight towards adipose-fin origin. Ventral profile of head convex. Ventral body profile slightly convex to nearly straight from pectoral-fin origin to pelvic-fin origin, and straight to slightly concave towards anal-fin origin. Body profile along anal-fin base posterodorsally slanted. Caudal peduncle elongate, nearly straight to slightly concave along dorsal and ventral margins.

Snout rounded from margin of upper lip to vertical through anterior nostrils. Head small. Mouth terminal. Maxilla extending posteriorly to under center of orbit, and slightly curved aligned at angle of approximately 45 degrees to longitudinal body axis. Anterodorsal border of maxilla concave and posterodorsal border slightly convex. Anteroventral and posteroventral borders convex. Maxilla slightly widened posteriorly.

Two tooth rows on premaxilla. Outer row with three or four, tricuspid or pentacuspid teeth with central cusp longer. Inner row with five teeth, gradually decreasing in length from first to third teeth; last two smaller, with five to seven cusps, with central cusp twice or three times longer and broader than other cusps. Maxilla with one or two (usually one), tricuspid or pentacuspid teeth, with central cusp longer. Three or four anteriormost dentary teeth larger, with seven cusps, followed by one or two teeth of medium sized with five cusps, and six teeth with one to three cusps or conical; central cusp in all teeth two to three times longer and broader than other cusps. All cusp tips slightly curved towards inside of mouth (Fig. 3).

Dorsal-fin rays ii, $9(\mathrm{n}=66)$; first unbranched ray approximately one-half length of second ray. Dorsal-fin origin located posterior to middle of SL and posterior to vertical through pelvic-fin origin. Dorsal-fin rays of males bearing one or two pairs of small retrorse bony hooks along posteroventral border of each lepidotrichia segment, usually between first and eighth branched rays, and located along posteriormost branch and on distal third length of each ray. Adipose-fin located approximately at vertical through insertion of base of $21^{\text {st }}-22^{\text {nd }}$ anal-fin rays.

Anal-fin rays ii-iv, 23-25 (rarely 22 or 26-27, mean $=24.2, \mathrm{n}$ =66). First unbranched ray visible only in c\&s specimens. Anal-fin profile smoothly concave in females, and nearly straight in males. Anal-fin origin posterior to vertical through base of last dorsal-fin ray. Anal-fin rays of males bearing one 
Table 1. Morphometric data of holotype ( $\mathrm{H}$, male) and paratypes of Astyanax elachylepis from rio Tocantins drainage $(\mathrm{n}=66$ including the holotype). $m$, males $(\mathrm{n}=18)$; , females $(n=48)$.

\begin{tabular}{lccc}
\hline & H & range & mean \\
\hline Standard length (mm) & 91.7 & $47.9-114.1$ & 73.6 \\
& Percents of Standard length & \\
Predorsal distance & 51.8 & $47.1-56.6$ & 53.3 \\
Prepelvic distance & 50.5 & $48.2-54.1$ & 51.5 \\
Prepectoral distance & 26.6 & $26.0-31.1$ & 28.7 \\
Preanal distance & 69.4 & $68.2-72.8$ & 70.7 \\
Depth at dorsal-fin origin & 38.7 & $37.7-42.0$ & 39.9 \\
Caudal peduncle depth & 12.6 & $11.3-12.8$ & 12.2 \\
Caudal peduncle length & 9.5 & $8.2-11.4$ & 9.5 \\
Anal-fin base & 29.3 & $25.8-30.0$ & 28.0 \\
Dorsal-fin length & 25.3 & $25.0-29.9$ & 27.2 \\
Pelvic-fin length (m) & 16.2 & $16.2-18.8$ & 17.6 \\
Pelvic-fin length (f) & - & $14.5-17.5$ & 16.6 \\
Pectoral-fin length (m) & 20.2 & $20.2-23.3$ & 21.8 \\
Pectoral-fin length (f) & - & $20.4-23.3$ & 21.7 \\
Head length & 25.8 & $25.5-31.4$ & 28.1 \\
& Percents of Head length & & \\
Snout length & 25.8 & $22.2-25.9$ & 23.7 \\
Upper jaw length & 44.8 & $41.6-47.0$ & 44.4 \\
Orbital diameter & 30.0 & $27.9-33.9$ & 29.8 \\
Interorbital width & 38.3 & $33.1-40.0$ & 36.1 \\
\hline
\end{tabular}

pair of small, elongate, retrorse bony hooks along posterolateral border of each segment of lepidotrichia, usually along last unbranched ray and $20^{\text {th }}$ branched rays; hooks more numerous along second through seventh branched rays. Hooks usually located along posteriormost branch and distal half to two-thirds length of each ray.

Pectoral-fin rays i, 11-15 (mean $=12.5, \mathrm{n}=66)$. Pectoral-fin tip not reaching pelvic-fin origin in males and females. Pectoral-fin rays of males similar to those present on dorsal-fin rays. Pelvic-fin rays i, $7(n=66)$. Pelvic-fin origin located anterior to vertical through dorsal-fin origin. Pelvic fin of males usually bearing one retrorse bony hook per lepidotrichia along ventromedial border of second to fourth branched rays. Hooks usually located along posteriormost branch and distal half to two-thirds length of each ray. Caudal-fin forked, with 19 principal rays. Dorsal procurrent rays 11-13 $(\mathrm{n}=2)$. Ventral procurrent rays $10-11(\mathrm{n}=2)$.

Scales cycloid, moderately large. Lateral line complete. Scales in longitudinal series 48-52 (rarely 53, mean $=49.9, \mathrm{n}=$ $65)$. Scale rows between dorsal-fin origin and lateral line 8-10 ( mean $=9, \mathrm{n}=66$ ); scale rows between lateral line and pelvicfin origin 6-8 (usually 7 , mean $=7 \cdot 1, \mathrm{n}=66$ ). Predorsal scales $12-15$, arranged in regular series $($ mean $=13.5)$. Scales rows around caudal peduncle 18-20 $($ mean $=19.5)$. Scale sheath along anal-fin base 12-22 scales in single series, extending to base of fifteenth to twenty-second branched ray.

Precaudal vertebrae 16-17; caudal vertebrae 19; total vertebrae 35-36. Supraneurals 5. Gill-rakers 7-8/10-11 $(n=2)$.

Color in alcohol. Dorsal and dorsolateral portion of head and body dark brown. Scales on lateral and ventral surface of body weakly pigmented. Two humeral spots; first black and narrow, large and vertically elongate, located over second to fourth lateral line scales and extending over five or six horizontal series of scales, including lateral line. Second humeral spot, dark and very diffuse, located on first series of scales above lateral line, between seventh to tenth series of scales and extending over two or three horizontal series of scales. Second humeral spot not visible in some specimens. Midlateral body with silvery stripe extending from humeral spot to caudal-peduncle. Large, horizontally elongate, black spot on caudal peduncle forming lozenge or square spot, and extending over middle caudal-fin rays. Remaining fins lacking distinctive patches of pigmentation (Fig. 2). Some specimens examined just some months after fixation in formalin (UNT 1891), yet presented dorsal, pelvic, anal and caudal fins red-orange pigmented.

Sexual dimorphism. Males of A. elachylepis are easily recognized by the presence of bony hooks on the dorsal-, anal-, pectoral-, and pelvic-fin rays (see Description). All males examined possess bony hooks along these fins $(76.5-115.0 \mathrm{~mm}$ SL). Males and females also slightly differ concerning pectoral and pelvic-fin lengths (Table 1) and anal-fin shape, which is concave in females and nearly straight in males.

Distribution. Astyanax elachylepis is known from rio Tocantins drainage, Brazil (Fig. 1).

Etymology. The name elachylepis is from Greek, elachis, small, short, little, plus lepis, meaning scales, alluding to the small size of scales. A noun in aposition.

\section{Discussion}

The new species is described in Astyanax according to the current definition of the genus, proposed by Eigenmann $(1921,1927)$. Astyanax elachylepis possess very high lateralline scales counts, an uncommon feature among the species on the genus, and also exhibited by $A$. anterior, A. bourgeti, A. erythropterus, A. festae, A. integer, A. microlepis, A. pellegrini, and $A$. symmetricus. The new species differs from these, but $A$. microlepis, by a smaller number of branched anal-fin rays (22-27 vs 28-45). Astyanax elachylepis differs from A. microlepis, described from Piedra Moler [upper río Cauca, Colombia], by a larger number of branched anal-fin rays (22-27 vs 19-22), presence of a larger spot in the caudalpeduncle, and by the presence of bony hooks in dorsal-, anal-, pelvic-, and pectoral-fin rays in males.

Astyanax maximus Steindachner, 1877, described from Tullumayo and Monterico in Peru, possess color pattern and maximum length very similar to A. elachylepis. However, the examination of four syntypes of $A$. maximus (NMW 57662, 57663 and 57664), revealed that all possess 39-40 lateral-line scales and 26-28 branched anal-fin rays. Five additional specimens of A. maximus (ANSP 136807 and 119875) were examined, which also exhibit 26-28 anal-fin rays and 38-41 lateralline scales. Given that these counts do not overlap the counts of the new species, and given the distance between the type 


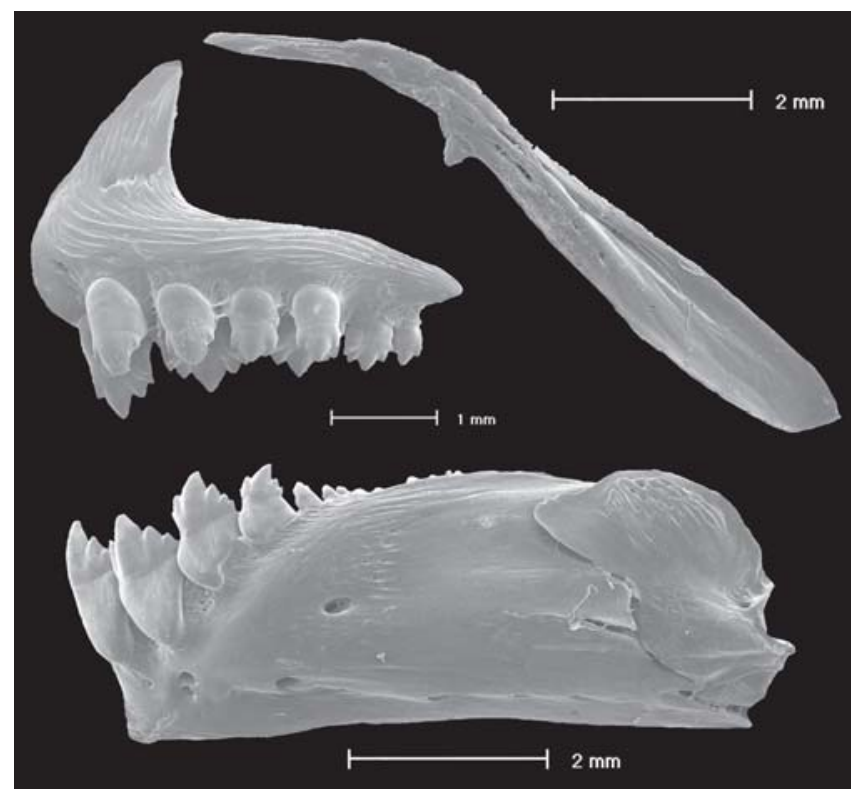

Fig. 3. Astyanax elachylepis, MCP 16054, paratype, female, $76.6 \mathrm{~mm}$ SL. Scanning electronic microscopy of left side upper and lower jaws teeth.

localities, we recognize $A$. elachylepis and $A$. maximus as distinct species.

The presence of bony hooks on the dorsal- and/or pectoral-fin rays has also been recently reported in three Astyanax species: A. ojiara Azpelicueta \& Garcia, 2000, A. troya Azpelicueta \& Casciotta, 2002, and A. leonidas Azpelicueta \& Casciotta, 2002. These species differ from A. elachylepis by lower lateral-line scales counts (34-38), and by the shape of the caudal-peduncle spot.

Three Astyanax species have previously been described from the rio Tocantins drainage: A. goyacensis Eigenmann, 1908, described from Goiaz [sic]; A. unitaeniatus Garutti, 1998, and $A$. argyrimarginatus Garutti, 1999. These species belongs to Astyanax bimaculatus species-group and possess a spot horizontally oval black humeral spot, and a single black longitudinal stripe, features absent in A. elachylepis.

The icthyofauna of the rio Tocantins drainage is poorly known. Reports on the icthyofaunal composition of the drainages are rare (e.g. Merona, 1987; Ferreira, 1993). The rio Tocantins drainage is an area of endemism for several Neotropical freshwater fish groups as identified by several authors (e.g. Vari, 1988; Menezes \& Lucena, 1998; Lima \& Moreira, 2003; Cardoso \& Lucinda, 2003; Fisch-Muller et al., 2001; 2005), especially in its upper portions.

Comparative material. Astyanax anterior: MCZ 89556 (lectotype, photograph), Tabatinga, Amazonas, Brazil. Astyanax microlepis: MHNUC 0188 (40, 26.5-57.3 mm SL), Zanjón Bagazal, rio Cauca drainage, Departamento del Cauca, Colombia, approx. $03^{\circ} 03^{\prime} \mathrm{N} 76^{\circ} 33^{\prime} \mathrm{W}$. USNM 79167 (4 paratypes, photograph, x-ray, 65.4-84.9 mm SL), Cartago, Colombia. Astyanax integer: CAS 123726 (holotype, photograph, x-ray, $84.9 \mathrm{~mm} \mathrm{SL}$ ), Guaicaramo, Colombia. Astyanax maximus: NMW 57662 (1), NMW 57663 (2),
NMW 57664 (1), syntypes, Monterico, Peru. ANSP 136807 (4 of 7, 56.6-66.1 mm SL), vicinity Tingo Maria, Huanucu, Peru, and ANSP 119875 (1, $109.5 \mathrm{~mm} \mathrm{SL})$, quebrada Pijuayali, tributary of rio Pachitea, Huanucu, Peru. Astyanax sp.: NRM 23670 (1, 138.2 $\mathrm{mm} \mathrm{SL}$ ), rio Corrientes, Teniente López, Loreto, Peru.

\section{Acknowledgments}

We are grateful to Luiz Malabarba and Pablo Lehmann for data and photography of Astyanax microlepis. This paper benefited from comments and criticisms by Cristiano Moreira (MZUSP), and two anonymous reviewers. We owe special thanks to Sandra Raredon (USNM) and Wellendorf Helmut (NMW) for the photographs of primary types of $A$. microlepis and $A$. maximus, respectively; to the Centro de Microscopia e Microanálises - CEMM, PUCRS for the SEM preparations; to Alexandre Charcansky (MCP) by assistance in the figure of teeth; to Mark Sabaj (ANSP), Osvaldo Oyakawa, C. Moreira (MZUSP) for selection and loan of specimens. We thank the Laboratório de Ictiologia Sistemática da Universidade Federal do Tocantins (UNT), and the Laboratório de Ictiologia da Pontifícia Universidade Católica do Rio Grande do Sul (MCP) for support during this study. The senior author has a doctoral fellowship from Coordenação de Aperfeiçoamento de Pessoal de Nível Superior (CAPES).

\section{Literature cited}

Baird, F. S. \& C. Girard, 1854. Descriptions of new species of fishes collected in Texas, New Mexico and Sonora, by Mr. John H. Clark, on the U.S. and Mexican Boundary Survey, and in Texas by Capt. Stewart Van Vliet, U.S.A. Proceedings of the Academy Natural Sciences, Philadelphia, 1854:24-29.

Cardoso, A. R. \& P. H. F. Lucinda, 2003. Three new species of Hemiancistrus (Teleostei: Siluriformes: Loricariidae) from the rio Tocantins basin with comments on the genus. Ichthyological Exploration of Freshwaters, 14(1): 73-84.

Eigenmann, C. H. 1921. The American Characidae. Part 3. Memoirs of Museum of Comparative Zoology, 43: 208-310.

Eigenmann, C. H. 1927. The American Characidae. Part 4. Memoirs of Museum of Comparative Zoology, 43: 311-428.

Ferreira, E. F. G. 1993. Composição, distribuição, e aspectos ecológicos da ictiofauna de um trecho do rio Trombetas, na área de influência da futura UHE Cachoeira Porteira, Estado do Pará, Brasil. Acta Amazonica, 23: 1-89.

Fink, W. L. \& S. H. Weitzman. 1974. The so-called cheirodontin fishes of Central America with descriptions of two new species (Pisces: Characidae). Smithsonian Contributions to Zoology, 172: 1-46.

Fisch-Muller, S., R. Mazonni \& C. Weber. 2001. Genetic and morphological evidences for two new sibling species of Ancistrus (Siluriformes: Loricariidae) in upper rio Tocantins drainage, Brazil. Ichthyological Exploration of Freshwaters, 12(4): 289-304.

Fisch-Muller, S, A. R. Cardoso, J. F. P. da Silva \& V. A. Bertaco. 2005. Three new species of Ancistrus Kner (Teleostei: 
Siluriformes: Loricariidae) from the upper Tapajós and Tocantins rivers. Revue Suisse de Zoologie, 112(2): 559-572. Lima, F. C. T, L. R. Malabarba, P. A. Buckup, J. F. Pezzi da Silva, R. P. Vari, A. Harold, R. Benine, O. T. Oyakawa, C. S. Pavanelli, N. A. Menezes, C. A. S. Lucena, M. C. S. L. Malabarba, Z. M. S. Lucena, R. E. Reis, F. Langeani, L. Casatti, V. A. Bertaco, C. Moreira \& P. H. F. Lucinda. 2003. Genera incertae sedis in Characidae. Pp. 134-141. In: R. E. Reis, S. O. Kullander \& C. J. Ferraris (Eds.). Check List of the Freshwater Fishes of South and Central America. Edipucrs, Porto Alegre, $729 \mathrm{p}$.

Lima, F. C. T. \& C. R. Moreira. 2003. Three new species of Hyphessobrycon (Characiformes: Characidae) from the upper rio Araguaia basin in Brazil. Neotropical Ichthyology, 1(1):21-33.

Menezes, N. A. \& C. A. S. Lucena. 1998. Revision of the subfamily Roestinae (Ostariophysi: Characiformes: Cynodontidae). Ichthyological Exploration of Freshwaters, 9(3): 279-291.

Merona, B. 1987. Aspectos ecológicos da ictiofauna no baixo Tocantins. Acta Amazônica, 16-17: 104-109.
Taylor, W. R. \& G. C. Van Dyke. 1985. Revised procedures for staining and clearing small fishes and other vertebrates for bone and cartilage. Cybium, 9: 107-119.

Vari, R. P. 1988. The Curimatidae, a lowland neotropical fish family (Pisces: Characiformes): Distribution, endemism, and phylogenetic biogeography. Pp. 343-377. In: P. E. Vanzolini \& W. R. Heyer (eds). Proceedings of a workshop on Neotropical distribution patterns. Academia Brasileira de Ciências, Rio de Janeiro, 488 p.

Weitzman, S. H. \& L. R. Malabarba. 1998. Perspectives about the phylogeny and classification of the Characidae (Teleostei: Characiformes). Pp. 161-170. In: L. R. Malabarba, R. E. Reis, R. P. Vari, Z. M. S. Lucena, and C. A. S. Lucena (eds.). Phylogeny and Classification of Neotropical Fishes. Edipucrs, Porto Alegre.

Received April 2005 Accepted September 2005 